the Bush request. “The NIH's absolute zero increase is going to strike very deeply into the heart of American research," he says.

Over at NASA, things are looking up for those who look down. The agency is budgeting to reinstate three climate sensors that had previously been removed to the pilot mission for the next generation of weather and climate monitors, the National Polar-orbiting Operational Environmental Satellite System. And following a recommendation from the US National Academies, the agency is planning to start five new Earth-observation missions in the next six years, including a satellite to measure soil moisture set for a 2012 launch, and a laser altimeter to measure ice thickness in 2015. Three other new missions, as prioritized by the academies' report, will be announced soon, at a cost of $\$ 910$ million over five years.

NASA's budget request also includes \$344 million in the next five years for three small lunar missions to be launched by 2014 - a dust monitor and two geophysical stations for the Moon's poles that will form part of an international network. Asked whether the new lunar science represented a renewed commitment to Bush's vision of future Moon exploration, NASA associate administrator for science Alan Stern said: "You could say, empirically, it does."

Finally, NASA announced that work would begin on the next major astrophysics flagship launch: the Joint Dark Energy Mission. The project, also funded by the DOE, was ranked first by a recent National Academies report and may fly by 2015 .

Eric Hand, Meredith Wadman, Rachel Courtland, Mitch Waldrop and Jeff Tollefson

\title{
The Moon: destination or distraction?
}

A high-level meeting next week will offer scientists a chance to re-examine NASA's commitment to human exploration of the Moon. The 12 February workshop is organized by the Planetary Society, a space-exploration advocacy group based in Pasadena, California. It is timed to come four years after President George W. Bush called for a return to the Moon in his Vision for Space Exploration (VSE), and a week after the last of the budget requests with which he might have furthered that vision (see page 610). As such, it might thus mark the opening of the post-Bush era in space exploration.

Conceived in the wake of the Space Shuttle Columbia disaster, the VSE's goals were to finish the International Space Station (ISS), replace the shuttle, return crews to the Moon, and eventually explore Mars. But the expense of shuttle operations and ISS construction has led to cuts in the VSE's budget, as well as in that for space science. "The Vision for Space Exploration doesn't have enough public support to generate the budget it needs," says Planetary Society director Louis Friedman. "We have an adequate window to discuss whether the lunar programme has been constructed correctly."

On the list to attend the two-day, invitation-only meeting at Stanford University in California are 50 prestigious figures including astronauts, former aerospace-industry chief executives, a handful of former NASA associate administrators and, most importantly perhaps, the advisers to two of the presidential candidates.

Given the budgetary constraints, some of the participants want alternatives to Moon missions. One target would be the near-Earth asteroids, some of which are within the range of the Ares 1 rocket that is under development for the VSE. Because of the asteroids' low gravity, they could be landed on with a slightly modified version of the Crew Exploration Vehicle, being developed as a replacement for the Space Shuttle. Other proposals would take a crew not to natural targets but to artificial ones, such as the James Webb Space Telescope, an infrared replacement for the farther from Earth. These missions would offer a chance to practise the long trips required for interplanetary travel without incurring the costs of lunar landings.

Some see a subtext here - a desire to avoid building expensive lunar infrastructure and instead focus on something more exciting. "The real reason Mars advocates like asteroids is because we aren't going to build a base on an asteroid," says James Muncy, a space-policy consultant and former adviser to the Reagan and current Bush administrations. The Planetary Society has long pushed for Mars missions,

\section{Carbon burial buried}

The US Department of Energy has pulled out of a flagship project to build the first 'clean' coal-fired power plant in the United States, a move that will kill the project unless supporters can rouse Congress on its behalf.

The FutureGen project was intended to demonstrate technologies for capturing and burying carbon dioxide from coal-fuelled power plants; it was scheduled to begin operating in 2012. But its costs have nearly doubled to $\$ 1.8$ billion in recent years, and last week the department pulled out of the deal after failing to reach a new funding agreement with its private partner, the FutureGen Industrial Alliance, which consists of more than a dozen energy companies. The energy department had been slated to pick up threequarters of the bill for the 275megawatt plant.

"I'm disappointed because I thought there was a lot more good than bad in the project,"

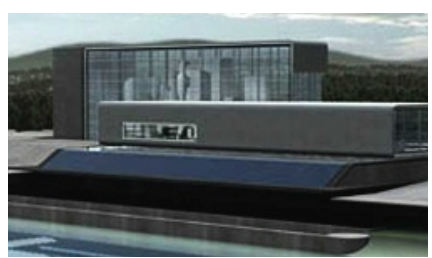

Soaring costs mean the FutureGen power plant may never be built.

says Howard Herzog, a carbonsequestration expert at the Massachusetts Institute of Technology in Cambridge.
"It's hard for me to see this not delaying overall progress."

In the project's place, the administration says it will help companies add carbon-capture and -sequestration equipment to new or existing coal plants that have at least $\mathbf{3 0 0}$ megawatts of capacity. Officials say this will ultimately save taxpayers money while allowing the technology to spread more quickly.

The abrupt decision has infuriated members of the FutureGen alliance and the project's political supporters 


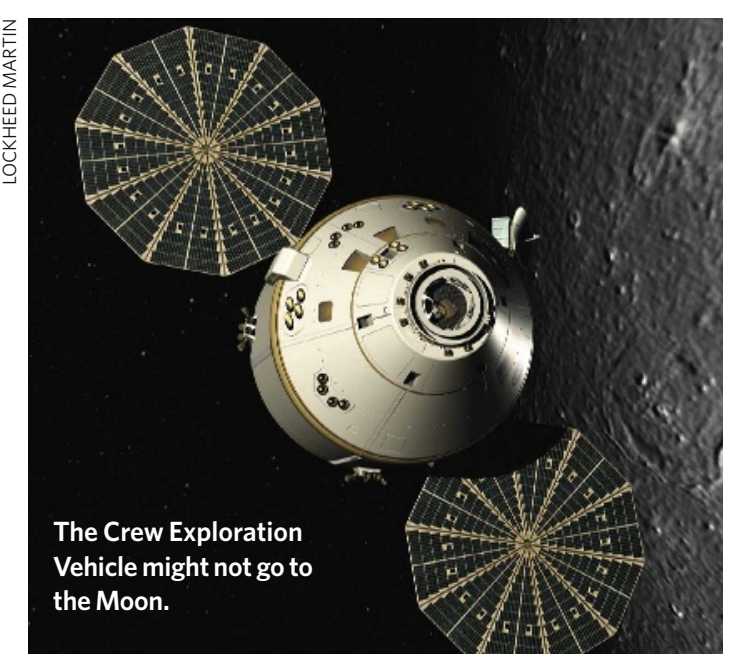

McCain (who has been endorsed by Sean O'Keefe, the former NASA administrator who launched the VSE) and former Massachusetts Governor Mitt Romney, was not intentional. Rather the Democratic advisers were included incidentally, as the Planetary Society is one of Garver's clients and Levin is a member of its board.

The Stanford workshop group is just one of many fighting for the attention of such people. "Theirs will be one more report added to dozens of other inputs that these transition teams are going to get," says Alan Ladwig, a former NASA associate administrator who supports the current programme. "Unless one has the and one of the meeting's conveners is Stanford professor G. Scott Hubbard, a former head of the NASA Mars programme. Hubbard says that, although he personally wants to speed up Mars exploration, there is no preconceived result for the workshop. But Mike Griffin, the NASA administrator, says in an e-mail to Nature that some of the workshop organizers had a long-standing rejection of the Moon as a place to explore. "Balanced choices must be made," Griffin says. "But they cannot be continually remade if there is to be progress."

A new administration, though, does offer a chance to make new policy - and to appoint new administrators. "This is absolutely the season for these things," says Muncy. Lon Levin and Lori Garver, who are space-policy consultants and advisers to Democrat presidential-hopefuls Barack Obama and Hillary Clinton, are the sort of attendees who might feed the results of the workshop into new policy. Hubbard says that the exclusion of advisers to major Republican candidates, Senator John private number of a presidential candidate, I can't imagine that it will have all that much of an impact."

But the Stanford group has a precedent. After Bush issued the skeletal version of the VSE in January 2004, many groups followed up with reports on how best to implement it. In the summer of 2004, Griffin, then at Johns Hopkins University's Applied Physics Laboratory in Laurel, Maryland, and Owen Garriott, a former astronaut, produced their own report on the VSE, commissioned by the Planetary Society. They shopped the report around the White House and Congress, where it was received favourably. By April of 2005, Griffin was NASA administrator and his report was, for the most part, subsequently implemented. "I'm sure that some of [the workshop attendees] would hope to get on one of the transition teams or get some kind of political appointment or return to NASA as a result of their activity," says Ladwig.

Eric Hand on Capitol Hill. As recently as December, when the alliance announced that the plant would be located in Mattoon, Illinois, the energy department called the project a "cornerstone" of the administration's vision for clean coal. But deputy energy secretary Clay Sell says he realized FutureGen was in trouble when the cost estimate came out nine months before that. "I knew that this would not end well when I saw that baseline increase so dramatically this early in the process," he says.
Although the energy department and the alliance had agreed to split any further cost overruns evenly, Sell says the department objected when the alliance insisted

\section{"There was a lot more good than bad in the project."}

on financing its share of the project by taking out a loan - essentially reducing its cash contribution.

Rising prices for plant components such as steel and concrete, as well as labour, pushed the price tag from $\$ 950$ million to $\$ 1.5$ billion, says Michael Mudd, the alliance's chief executive. He points out that the additional $\$ 300$ million that boosts total costs to $\$ 1.8$ billion represents operating costs that will be recovered through electricity sales.

"We are going to work with Congress to make sure that the legislative language exists to keep it viable and on track as is," Mudd says. Jeff Tollefson 